\title{
LOWER FORMULATION pH DOES NOT ENHANCE BENTAZONE UPTAKE INTO PLANT FOLIAGE
}

\author{
Z.Q. LIU \\ Plant Protection Chemistry ${ }_{N Z}$, Forest Research, Private Bag 3020, Rotorua \\ Corresponding author: Zhiqian.Liu@forestresearch.co.nz

\section{ABSTRACT} \\ Lower $\mathrm{pH}$ generally favours the diffusion of weak acid compounds in vitro \\ into plant cells. Such a rule may not be applicable to the uptake of formulated \\ weak acid herbicides applied to plant foliage in vivo. In this study, the \\ effect of spray formulation $\mathrm{pH}(5,7$ and 9$)$ on the foliar uptake of a weak \\ acid herbicide, bentazone which is used as a formulated salt, was investigated \\ using three plant species, mustard (Sinapis alba), wheat (Triticum aestivum) \\ and bean (Vicia faba). Greater uptake of the herbicide occurred at $\mathrm{pH} 9$ and \\ $\mathrm{pH} 7$ than at pH 5 on mustard and wheat leaves. Uptake of bentazone into \\ bean was slow $(<20 \%$ after $24 \mathrm{~h}$ ) regardless of carrier $\mathrm{pH}$. However, in the \\ presence of a surfactant, faster uptake was achieved with higher $\mathrm{pH}$. The \\ results are discussed in relation to the lipophilicity and the solubility of \\ weak acid chemicals as influenced by $\mathrm{pH}$. \\ Keywords: uptake, bentazone, weak acid herbicides, $\mathrm{pH}$.
}

\section{INTRODUCTION}

Most post-emergence herbicides are weak acid compounds. It is generally believed that for such chemicals, uptake into plant tissues is greater at lower carrier $\mathrm{pH}$, due to a higher proportion of the molecules being present in an undissociated form. However, data supporting this statement were mostly obtained with plant tissues immersed (Van Ellis \& Shaner 1988; Liu 1993) or cultured cells incubated (Sterling et al. 1990; Liebl et al. 1992; Gronwald et al. 1993) in a solution of unformulated weak acid herbicides.

There are surprisingly few reports in the literature about the effect of carrier $\mathrm{pH}$ on the uptake of weak acid herbicides applied as commercial formulations, generally watersoluble salts, onto plant foliage in vivo. Results are often conflicting. For example, Sterling \& Lownds (1992) reported that picloram absorption into broom snakeweed reached a maximum at $\mathrm{pH} 4$ and declined at higher $\mathrm{pH}$, whereas Thompson et al. (1996) found that the uptake of the same herbicide into leafy spurge was greater at $\mathrm{pH} 7$ than at $\mathrm{pH} 5$. In the case of bentazone, no information is available regarding the possible effect of treatment solution $\mathrm{pH}$ on its uptake into plant foliage when used as a formulated salt.

The objective of this work was to investigate the effect of carrier $\mathrm{pH}$ on the uptake of bentazone, applied both as an unformulated acid and as a sodium salt, into three different plant species, mustard, wheat and bean.

\section{Plants}

\section{MATERIALS AND METHODS}

Mustard (Sinapis alba), bean (Vicia faba cv. Evergreen) and wheat (Triticum aestivum cv. Advantage) seedlings were raised from seed in pots containing a peat-based potting mix ("Bloom", Yates NZ Ltd) in a controlled environment $\left(20^{\circ} \mathrm{C} / 15^{\circ} \mathrm{C}\right.$, day/night temperature; $70 \% \mathrm{RH} ; 12 \mathrm{~h}$ photoperiod with light intensity ca $\left.500 \mu \mathrm{mol} / \mathrm{m}^{2} / \mathrm{s}\right)$. Three week old mustard plants and four week old bean and wheat plants were used for the experiments.

Chemicals

One surfactant, Lutensol AO $5\left(\mathrm{C}_{13} / \mathrm{C}_{15}\right.$ linear alcohol ethoxylate, mean ethylene oxide content $=5$, BASF, Germany) was used at $0.1 \%$ and $0.5 \%$ concentrations $(\mathrm{w} / \mathrm{v})$.

New Zealand Plant Protection 55:163-167 (2002) 
${ }^{14} \mathrm{C}$-Bentazone (3-isopropyl- $1 H$-2,1,3-benzothiadiazin-4(3H)-one-2,2-dioxide; specific activity: $1.2 \mathrm{GBq} / \mathrm{mmol})$, technical bentazone acid ( $99.5 \%$ pure) and a commercial formulation of bentazone sodium salt (Basagran) were supplied by BASF, Germany. Radiolabelled bentazone was added to the unlabelled bentazone acid or bentazone sodium salt in phosphate buffer at $\mathrm{pH} \mathrm{5,7}$ or 9 just before use. An aqueous dispersion of the surfactant was then added as appropriate. The final treatment formulations contained $0.05 \%$ bentazone sodium salt (a.e.) with mustard and wheat plants, and $0.002 \%$ to $0.2 \%$ bentazone sodium salt (a.e.) or bentazone acid with bean plants.

Determination of bentazone uptake

Twelve droplets $(0.24 \mu \mathrm{l})$ of treatment formulations containing ${ }^{14} \mathrm{C}$-bentazone $(10000$ $15000 \mathrm{dpm}$ ) were applied by microsyringe to the adaxial leaf surface of bean (a single third leaf), wheat (the youngest fully expanded leaf) or mustard (one of the first pair of true leaves) plants. Each treatment consisted of five replicates of individual plants. Uptake was determined by washing residual bentazone from the treated leaf surfaces at $4 \mathrm{~h}$ or $24 \mathrm{~h}$ after treatment (HAT) and calculating the amount absorbed as described by Gaskin (1995).

All uptake results were subjected to analysis of variance, and treatments were compared using least significant difference (LSD) tests.

\section{RESULTS}

Effect of carrier pH on the uptake of bentazone-Na into mustard

The uptake of bentazone-Na into mustard leaves was $\mathrm{pH}$ dependent, with greatest uptake ( $48 \%$ at $4 \mathrm{HAT}$ and $76 \%$ at $24 \mathrm{HAT}$ ) occurring at $\mathrm{pH} 9$. Decreasing the carrier $\mathrm{pH}$ resulted in reduced bentazone-Na uptake both at 4 HAT and 24 HAT (Fig. 1).

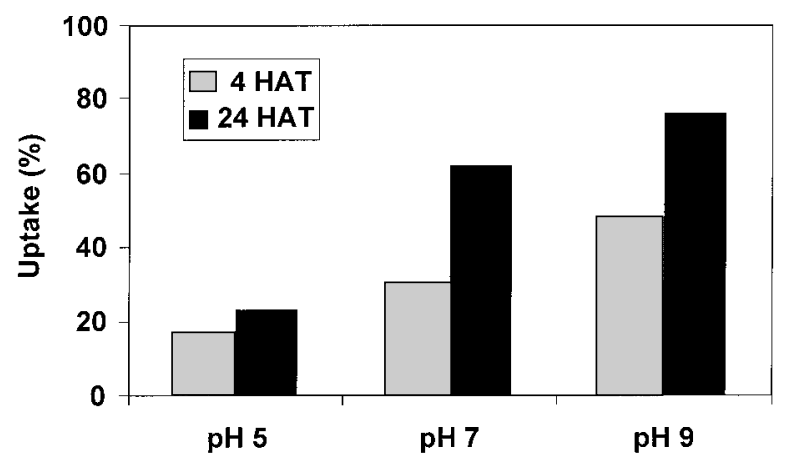

FIGURE 1: Effect of carrier pH on the uptake of bentazone-Na into mustard (LSD $(\mathbf{P}<0.05)=12)$

Effect of carrier $\mathrm{pH}$ on the uptake of bentazone-Na into wheat

The uptake of bentazone-Na into wheat foliage was slower than into mustard foliage. Again, carrier $\mathrm{pH}$ significantly affected the uptake, with higher uptake being achieved at $\mathrm{pH} 7(56 \%$ at $24 \mathrm{HAT})$ and $\mathrm{pH} 9(41 \%$ at $24 \mathrm{HAT})$. Uptake was very poor (3\% at $24 \mathrm{HAT})$ at $\mathrm{pH} 5$ (Fig. 2).

Effect of carrier $\mathrm{pH}$ on the uptake of bentazone-Na into bean

The uptake into bean foliage of bentazone-Na applied without surfactant at both $0.05 \%$ and $0.2 \%$ concentrations was low $(<20 \%$ at $24 \mathrm{HAT})$, regardless of carrier $\mathrm{pH}$ (Table 1$)$. The addition of the surfactant AO 5 generally increased bentazone uptake, although the enhancing effect varied with the concentrations of both the active ingredient and the 


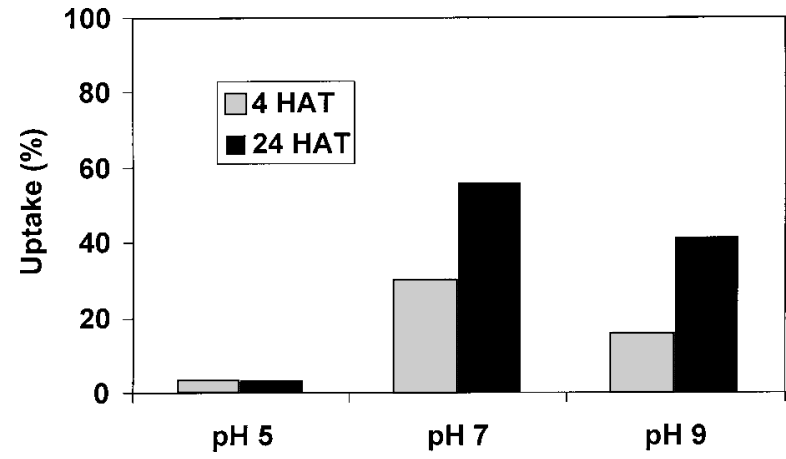

FIGURE 2: Effect of carrier $\mathrm{pH}$ on the uptake of bentazone-Na into wheat (LSD $(\mathbf{P}<\mathbf{0 . 0 5})=7)$

surfactant. In the presence of the surfactant, carrier $\mathrm{pH}$ had no significant effect on uptake in most cases. Higher $\mathrm{pH}$ produced greater uptake only when high active ingredient and surfactant concentrations were combined.

TABLE 1: Effect of carrier pH and surfactant (AO 5) on the uptake (\%) of bentazone-Na into bean leaves at $24 \mathrm{~h}$ after treatment.

\begin{tabular}{|c|c|c|c|c|c|c|}
\hline \multirow[t]{2}{*}{ Carrier pH } & \multicolumn{3}{|c|}{$0.05 \%$ bentazone- $\mathrm{Na}$} & \multicolumn{3}{|c|}{$0.2 \%$ bentazone- $\mathrm{Na}$} \\
\hline & $\begin{array}{c}\text { No } \\
\text { surfactant }\end{array}$ & $0.1 \%$ & $0.5 \%$ & No & $0.1 \%$ & $0.5 \%$ \\
\hline 5 & 18 & 47 & 80 & 14 & 29 & 45 \\
\hline 7 & 19 & 42 & 73 & 16 & 30 & 57 \\
\hline 9 & 14 & 44 & 76 & 18 & 29 & 67 \\
\hline LSD $(\mathrm{P}<0.0$ & & 11 & & & 9 & \\
\hline
\end{tabular}

\section{Effect of carrier $\mathrm{pH}$ on the uptake of bentazone acid into bean}

The uptake of bentazone acid into bean was $\mathrm{pH}$ dependent only when applied at a very low concentration $(0.002 \%)$ : the lower the carrier $\mathrm{pH}$, the greater the uptake (Table 2 ). However, lower $\mathrm{pH}$ could no longer provide greater uptake when bentazone concentrations were $\geq 0.01 \%$.

TABLE 2: Effect of carrier $\mathrm{pH}$ on the uptake (\%) of bentazone acid into bean leaves at $24 \mathrm{~h}$ after treatment.

\begin{tabular}{|c|c|c|c|c|}
\hline \multirow{2}{*}{ Carrier $\mathrm{pH}$} & \multicolumn{4}{|c|}{ Bentazone acid concentration } \\
\hline & $0.002 \%$ & $0.01 \%$ & $0.05 \%$ & $0.2 \%^{1}$ \\
\hline 5 & 53 & 22 & 21 & 6 \\
\hline 7 & 30 & 19 & 24 & 9 \\
\hline 9 & 21 & 21 & 21 & 15 \\
\hline LSD $(\mathrm{P}<0.05$ & \multicolumn{4}{|c|}{8} \\
\hline
\end{tabular}

${ }^{1}$ Dissolved in $50 \%$ acetone. 


\section{DISCUSSION}

The mechanism of absorption of weak acid herbicides into plant cells has been extensively investigated (Van Ellis \& Shaner 1988; Sterling et al. 1990; Gronwald et al. 1993). Generally, the absorption is $\mathrm{pH}$-dependent with the greatest amount of herbicide penetration occurring at acidic external $\mathrm{pH}$. All compounds studied were absorbed across membranes via simple diffusion and accumulated in plant cells via an energy-dependent, ion-trapping mechanism (Sterling et al. 1990). Because all these studies were conducted with plant tissues, cultured cells or protoplasts immersed in a radioactive herbicide solution, active ingredient solubility was not a problem. In such simple cases, absorption was mainly determined by the ratio of acid molecules to their anions. At lower solution $\mathrm{pH}$, higher proportions of the weak acid molecules were present in an undissociated form, which diffused readily across the membrane. In contrast, at higher $\mathrm{pH}$ more molecules were in a polar and dissociated form, so they traversed the membrane slowly.

When these weak acid molecules or their formulated salts are applied onto plant foliage, two factors can affect the uptake: active ingredient polarity and solubility in droplet residue. Low carrier $\mathrm{pH}$ produces more undissociated molecules that have low solubility and could crystallise on the leaf surface so that they are no longer available for uptake. High carrier $\mathrm{pH}$ produces more anions, which have higher water solubility and will stay in solution for a longer time. Although diffusion through the cuticle is expected to be slow for such polar anions, the fact that the uptake can occur over a long time may offset this. The greater uptake of bentazone-Na at higher $\mathrm{pH}$ observed in this work may result from this. Thus solute solubility is critical for foliar uptake. This may explain why different salts of phenoxy acid herbicides have different efficiency, with amine salt $>$ ammonium salt > sodium or potassium salt (Su 1989). Water solubility for these salts follows the same order for any given herbicide. Another example showing the importance of solubility in foliar uptake is the different uptake behaviour of glyphosate acid and its isopropylamine (IPA) salt. Glyphosate IPA salt always shows faster uptake than glyphosate acid, despite the latter being more lipophilic (Nalewaja et al. 1996).

This study has shown that when bentazone acid was used at extremely low concentration, active ingredient solubility was not a limiting factor, and the degree of molecular ionisation became the major factor to determine uptake. Thus, higher uptake was found at lower $\mathrm{pH}$. When the concentration of the acid was increased, active ingredient solubility again became critical and low $\mathrm{pH}$ could no longer provide greater percentage uptake. It can be concluded from this study that when bentazone is applied as a formulated sodium salt on plant foliage, lower carrier $\mathrm{pH}$ does not provide greater uptake.

\section{REFERENCES}

Gaskin, R.E. 1995: Effect of organosilicone surfactants on the foliar uptake of herbicides: stomatal infiltration versus cuticular penetration. In: Gaskin, R.E. ed. Proc. 4th Int. Symp. on Adjuvants for Agrochemicals, Melbourne. Pp. 243-248.

Gronwald, J.W.; Jourdan, S.W.; Wyse, D.L.; Somers, D.A.; Magnusson, M.U. 1993: Effect of ammonium sulfate on absorption of imazethapyr by quackgrass (Elytrigia repens) and maize (Zea mays) cell suspension cultures. Weed Sci. 41: 325-334.

Liebl, R.A.; Zehr, U.B.; Teyker, R.H. 1992: Influence of nitrogen form on extracellular pH and bentazon uptake by cultured soybean (Glycine max) cells. Weed Sci. 40: 418-423.

Liu, Z.Q. 1993: Mechanisms of absorption of pendimethaline and imazaquin by dodder seedlings. Acta Agriculturae Nucleatae Sinica 7: 231-236.

Nalewaja, J.D.; Devilliers, B.; Matysiak, R. 1996: Surfactant and salt affect glyphosate retention and absorption. Weed Res. 36: 241-247.

Sterling, T.M.; Balke, N.E.; Silverman, D.S. 1990: Uptake and accumulation of the herbicide bentazon by cultured plant cells. Plant Physiol. 92: 1121-1127.

Sterling, T.M.; Lownds, N.K. 1992: Picloram absorption by broom snakeweed (Gutierrezia sarothrae) leaf tissues. Weed Sci. 40: 390-394. 
Su, S.Q. 1991: Phenoxy acids. In: Su, S.Q. ed. Guidelines for herbicides. Scientific Press, Beijing. Pp. 25-54.

Thompson, W.M.; Nissen, S.J.; Masters, R.A. 1996: Adjuvant effects on imazethapyr, 2,4-D and picloram absorption by leafy spurge (Euphorbia esula). Weed Sci. 44: 469-475.

Van Ellis, R.M.; Shaner, D.L. 1988: Mechanism of cellular absorption of imidazolinones in soybean (Glycine max) leaf discs. Pesticide Sci. 23: 25-34. 